Henry Jeffreys*

$\underline{5 \text { May } 2008 \text { University of Stellenbosch }}$

\title{
Freedom of association + freedom of speech $=$ freedom of the media?
}

Thank you very much for the opportunity to participate in this important conference marking World Press Freedom Day. The conference theme poses an interesting conundrum, at least in the way I interpret it. Does freedom of association plus freedom of speech equal freedom of the media?

My immediate response would be to ask whether the three concepts or rights as they are stated in the Bill of Rights of the South African constitution, are mutually exclusive. I would think not. They are of equal importance, linked and mutually enforcing. The constitution guarantees each one of them and it seems to me that our democratic life would be a lot poorer should any of them end up being eroded.

In respect of freedom of association the Bill of Rights is very straightforward and clear. It simply states: 'Everyone has the right to freedom of association'. In a country with a history such as ours, this of course becomes a lot more complex in practice, as evidenced by the recent furor surrounding the meeting between the leader of the ANC, Jacob Zuma, and the Forum for Black Journalists (FBJ).

What this furor clearly showed was that not all South Africans think or feel the same about these issues.

The South African National Editors' Forum (Sanef) took a strong position against the decision by the FBJ to exclude white journalists from a briefing, not as we understood organized for their members only, but also for black journalists who were not members of the organization. In our view this effectively meant the exclusion of white journalists from the briefing - a matter of great public interest - simply because they were white.

It was Sanef's view that such exclusion from what was a public briefing by probably the most important political leader in the country, has no place in South Africa today. An important element of Sanef's position that ended up lost in the din surrounding the controversy, was our very clear view on the FBJ's right to organize and associate as it sees fit. In fact, Sanef has over the years expressed its concerns for the lack of effective professional and workplace organization amongst the country's non-managerial journalists.

However, as with all rights, the right to freedom of association should be claimed in ways that build and broaden the open society rather than narrowing it down.

I would now like to say something about freedom of expression and freedom of the media. We are, in South Africa, extremely fortunate to have these freedoms constitutionally enshrined and guaranteed. Unlike the simple, open-ended declaration on freedom of expression, our constitutional writers saw fit to be a bit more prescriptive and precise on what the rights to freedom of speech and freedom of the media may not do.

Allow me to quote from the Bill of Rights: 


\section{Freedom of expression}

1.Everyone has the right to freedom of expression, which includes:
a. freedom of the press and other media;
b. freedom to receive or impart information or ideas;
c. freedom of artistic creativity; and
d. academic freedom and freedom of scientific research.

2. The right in subsection (1) does not extend to:
a. propaganda for war;
b.incitement of imminent violence; or

c.advocacy of hatred that is based on race, ethnicity, gender or religion, and that constitutes incitement to cause harm.

Of course these rights must be balanced with all the other rights listed in the Bill of Rights. For us in the media, and more particularly the journalistic media, these constitutionally entrenched rights represent the bedrock on which we build our craft and pursue our mission to inform, educate, entertain and, perhaps more importantly, give insight into a world which is becoming progressively complex.

So, as we mark World Press Freedom Day, it is perhaps opportune to pause and consider the state of our hard fought for freedoms.

Are we in trouble? Not yet, entirely. Are we heading towards trouble? Well, the signs are there that we might.

At the recent Mondi awards, Mr. Trevor Ncube, publisher of the Mail\&Guardian and the owner of several newspapers in Zimbabwe, saw it fit to caution South Africans to take care of the freedoms we enjoy in the media and as citizens: 'You must never take your freedoms for granted. Do not, now that you enjoy freedom, take it for granted that you will never lose it. We should take the threats very serious (sic?) and begin to toyitoyi, because, if we don't, we are bound to have serious problems.'

In my own view the most serious threat to media freedom currently is the ANC's investigation into the establishment of a statutory media tribunal. In a meeting with, amongst others, the deputy president of the ANC, Kgalema Motlanthe, the idea was mooted as an effort on the part of the ruling party to strengthen the media's own selfregulatory mechanisms. 
This is clearly nonsense and one can only hope that the ANC's investigation concludes that the media tribunal is a bad idea in a free society and that it should be scrapped. In the meantime, we should remain vigilant and ready to challenge the ruling party and Government (should the matter become official public policy) right up to the Constitutional Court.

There are a number of very worrying signs, including the messing around with the SABC for clearly political purposes and of course the Films and Publications Bill which, should it become law, will single-handedly render the media dysfunctional.

These gathering clouds should also impress upon us as journalists the need to rededicate ourselves to the basic principles of our craft and to pursue our historic mission. This is becoming increasingly difficult as the world changes around us. As in so many other sectors of society the media environment is undergoing revolutionary change that is changing day by day the way in which we pursue and deliver our craft.

The explosion of technology, and particularly the internet, has led to serious doubts about the viability and sustainability of certainly the printed newspaper. It is probably the most oft-asked question I get when asked to speak about the media.

There is, however, in my view, a more important question. Will journalism survive the fast changing media environment? On the one hand there are people who see these changes as beneficial to the free flow of information and imbuing greater control by individuals over how they consume information. Others again, and I guess I fall into this category, see it as moving into a world where information is asserted rather than interrogated in the tried and tested journalistic ways.

In my view there is no reason why the essential elements of journalism should change simply because the delivery platforms change. A book I often read for inspiration is Bill Kovach and Tom Rosenstiel's The Elements of Journalism. They remind us, amongst other things, that journalism's first obligation is to the truth and its first loyalty to the citizens. Its essence is a discipline of verification. Journalists must maintain an independence of those they monitor in power. Journalism must provide a forum for public criticism and compromise. It must strive to make the significant interesting and relevant and keep the news comprehensive and proportional. Finally, it must allow its practitioners to exercise their personal conscience. I find these useful guidelines in the pursuit of the perfect journalism which I don't think exist anywhere.

My sense is that if we, as the practitioners, continuously strive to live these elements, it will strengthen our capacity to defend ourselves against those who strive to curb the constitutional freedoms we enjoy.

Freedom of association, freedom of expression and freedom of the media are all part of the same construct of democratic life. We should pursue and live them all in the spirit of our much admired constitution with the emphasis on opening up the spaces for free and open dialogue. That is not only a challenge for the media, but for all citizens. 
doi: $10.5789 / 2-1-41$

Thank you.

* Henry Jeffreys is the editor of Die Burger 